\title{
The Impact Of Risk Management And Portfolio Diversification On The Mauritian Banking Sector
}

\author{
M. P Odit, University of Technology, Mauritius \\ K.Dookhan, University of Technology, Mauritius \\ J.C Marylin, University of Technology, Mauritius
}

\begin{abstract}
Contrary to conventional wisdom, there is no evidence that banks can, or have ever been able to, easily form portfolios containing negligible exposure to unsystematic risk. Since well-diversified portfolios are the bedrock upon which so much financial theory has been built upon. However, studies carried on such topic in the Mauritian context are scant. Therefore this paper aims at filling this gap and examines the degree to which the Mauritian banks uses risk management practices and techniques in dealing with different types of risk. The paper also investigates when Mauritian banks diversify their portfolios, do they reduce their risk exposures. A modified questionnaire has been developed and is divided into two parts, covering the six aspects of risk management techniques and the remaining six aspects concerning portfolio diversification. Data was freshly collected, using the Statistical Package for the Social Sciences Software, specifically the Cronbach's Alpha, the Pearson's Correlation Coefficients, one-way ANOVA and OLS estimates. This study has found that the three most important risks facing the Mauritian banks are market risk followed by operational risk, and credit risk. The Mauritian banks are somewhat efficient in managing risk through diversification of portfolios. Finally, the results indicate that there is a significant difference between the variables concerning whether to diversify locally or internationally. This proves that both can be used as a tool for risk management practices but there is a need to stress on foreign exchange exposures depending on the bank's risk appetite.
\end{abstract}

Keyword: Risk Management and Portfolio Diversification

\section{INTRODUCTION}

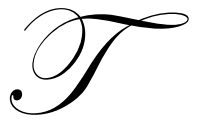

he Asian financial crisis is so far to run its full course, but is already one of the biggest crises in the post- war era. Consequently, it ruthlessly affected the performance of the region and created an economic depression that impacted on financial institutions worldwide. Moreover, these events occurred at a time when financial markets were still trying to cope with the contagions effects that shook the economies of Latin America.

However, while the specific conditions of the crises are certainly unique, the reactions of financial institutions were somewhat knowable. Immediately, following the outbreak of the Asian crisis, credit standards were tightened and leading growth was condensed. Some banks seemed to withdraw to their home markets, which looked more stable and attractive in short-term. These actions are very similar to the ones taken during the Latin America debt crisis in the 1980s or the global property downturn in the early 1990s. In fact, banks in countries like France, Sweden and Australia were hit very hard by the latter and imposed tied credit controls while they worked through their portfolios of bad loans.

Recently, the end 2008, financial crisis had laid banks to react immediately to changes in their culture and financial services precisely their capital structure concerning their operations. Among, those financial intermediaries 
which were severely hit were the Main Street Bank in Michigan, Bank of Clark Country in Washington and the latest State Bank of Aurora in Minnesota in March 2010. It is difficult to know which banks will fail. The Federal Deposit Insurance Corporation (FDIC) does not announce bank takeovers ahead of time. The best course of action is to make sure that the bank is observing the FDIC limits and not taking any risks. According to consultative paper issued by the Basel Committee on Banking Supervision (1999), for most banks, loans are the largest and most obvious source of credit risk. However, the Basel 2 regulation is to be expected to act as a 'watchdog' concerning the bank capital adequacy via the new rules that banks should follow, e.g., the credit risk rating framework.

Undoubtedly, risk management is the cornerstone of prudent banking practices. Risks in its nature are of utmost importance concerning any financial and non-financial institutions around the world. Many philosophers and gurus, for instance, Dembo (2006), Miller (1972) have made ample study on risk and about several mode of diversifying its consequences through a portfolio management theory. Modern Portfolio Theory, for which Harry Markowitz as jointly awarded the Nobel Prize in 1990, provides the academic bedrock for diversifying portfolios. Litan (1985), using IRS ${ }^{1}$ data over the 1974-89 period found gains from forming portfolios of bank and non-bank activities when using IRS rather than individual bank data. As a result, certain portfolios of bank and non-bank activities showed substantially higher returns for lower risk. Diversifying bank's activities internationally forms part in the risk management practices. Several studies have been undertaken to analyze the benefits of international ${ }^{2}$ portfolio diversification in developed as well as in emerging markets. Ali-Yrkko (2002), classifies the bank's motive to diversify as an economic, management and value maximization motive.

Banking operations have expanded rapidly over the past few decades, although banks in most countries still hold only a small percentage of their portfolio in foreign claims where there is a clear picture on the asset transformation function of banks and their exposure to non-diversifiable risks as argued by Hellwig (1998). With regards to portfolio diversification, it can be said that it is a widely embraced investment strategy that helps mitigate the unpredictability of markets for investors, Buffet (2007). Portfolio Theory applies equally to collections of credit risks as to equity and other investments. Hence the purpose of having a portfolio of assets instead of an asset is for the sole reason of reducing risks propaganda through diversification without sacrificing the rate of return, Rarimohan (2001). Sinkey (1984) suggested that an efficient portfolio achieves a specified rate of return with the minimum possible risk for the identified level of risk for the maximum possible rate of return. Hence the principle which underlines portfolio management is as he called 'diversification of risk'.

The paper lay emphasis of risk management in relation to portfolio diversification, precisely the issue of bank's internationalization against a well -defined, properly illustrated one, the mean-variance portfolio model, Markowitz (1952, 1959) and its worldwide extension Solnik (1973) and Secu (1980), where investors reap benefits from diversification.

\section{RISK MANAGEMENT WITH REGARDS TO PORTFOLIO DIVERSIFICATION}

Wright (2008), argued that there is no such thing as a risk free investment and mentioned some important risks that need to be taken into account namely shortfall risk, liquidity risk, reinvestment risk, inflation risk, market risk, interest rate risk, currency risk, economic risk, credit risk, and finally political risk. He insisted on his theory on risk management towards portfolio management that someone investment and portfolio should reflect his own goals, personal circumstances and risk tolerance. For him, there is no one-size -fits-all solution. Diversification simply means "not putting all of your egg in one basket. Asset class diversification is the primary way to manage volatility", Wright and Buffet (2006). However Nusbaum (2008) argued that 'a diversified portfolio should take risks but not a lot'. Reeves (2005) suggested that the objective of the exercise is to be able to obtain high risk adjusted rates of return that is the simple aim for investors is to make as much money as possible with a little risk of losing that money in the process as far as possible.

\footnotetext{
${ }^{1}$ An abbreviation for the Internal Revenue Service, a federal agency charged with the responsibility of administering and enforcing internal revenue laws.

${ }^{2}$ See Fowdar.S (2008), "International Portfolio Diversification: Assessing the Benefits of Investing In Africa"
} 
Gerard (2009) mentioned that informed decision making is core to effective risk management. Thompson (2008) suggested 'Three opportunities for Risk Management' with respect to the recent financial crisis where he argued about three sensible questions: Was it a weakness in risk management? Can we make sure it never happens again? Are there any opportunities for risk management to grasp? Regulators warned against over extending line of credit in 2005, 2006 and 2007. They knew that the US tax system encouraged taking out loans and even rewarded top up mortgages which as, 'silent second lien', the original lender knew nothing about. There was data in 2006 to suggest defaults were on the increase, as argued by Ellis (2008). Houses were being bought by people who were virtually guaranteed to be in negative equity twelve months after moving in.

Linbo Fan (2004) examined efficiency versus risk in large domestic USA banks where he found that profit efficiency is sensitive to credit risk and insolvency risk but not to liquidity risk or to the mix of loan products. In light of Basel 2 directives to reform the regulation of bank capital, there has been an extensive research on study of the bank loss loan portfolio density. Particular emphasis is on the measurement of the Value at Risk. A crucial input of a portfolio credit risk model is the suitable characterization of default correlations.

Pytkin (2004) and Cespedes, Herrero, Kreinin and Rosen (2006) explained the benefits of credit risk diversification when multiple common factors underlie default correlation. Furthermore, Hanson et al. (2005) explained how through simulation a two factor capital asset pricing model would lead to a reduction in the economic capital. Hahm (2004) conducted an empirical study on interest rate and exchange rate exposures of banking institutions in pre-crisis Korea where results indicated that Korean commercial banks and merchant banking bodies had been significantly exposed to both interest rate and exchange rate risk and that the subsequent profitability of commercial banks was significantly associated with the degree of pre-crisis exposure. Moreover the results indicated that the Korean case highlights the importance of updating financial supervision and risk management practices as a precondition for successful financial liberalization.

Niinimaki (2004) found that the magnitude of risk taking depends on the structure and side of the market in which competition takes place and concluded that if a bank is a monopoly and banks are competing only on the loan market then deposit insurance has no effect on risk taking. Wetmore (2004) examined the relationship between liquidity risk and loans-to-core deposits ratio of large commercial banks holding bodies. He pointed out that the average loan-to-core deposit ratio had increased over the period studied, which has an alternation in the asset/liability management practices of banks. He concluded that there is an upbeat connection occurring between market risk and the change in loan-to-core deposits ratio after 1994, with a negative relationship occurring before 1994.

Allen and Santomero (1998) argued that diversification improves bank's fundamental role in risk management. Beale, Jonghe and Vennet (2006), Stiroh (2006), has identified the need to assess the endogeneity of diversification decision. Reisen (2000) concluded that international diversification reduces risk easier than domestic diversification in the sense that securities reveal stronger correlations as a result of their joint exposure to country specific shocks. In fact, globalization is likely to raise the expected return for a given risk level. The diversification benefits are therefore, for the reduction of risk resulting in markets that are practically uncorrelated and negatively correlated. The empirical work of Butler and Jaoquin (2001) found that the fundamental rational for international portfolio diversification expands the opportunities for gains from portfolio diversification afar from those that are available through domestic securities. Arouri (2004) showed that international diversification is often considered as the best mechanism to improve portfolio performance. In fact, correlation between asset returns from different markets is minor than correlation within the same market.

\section{THE MAURITIAN BANKING SECTOR}

Mauritius has a long tradition of commercial banking dating back to 1812 , until 2004, the banking sector was divided into two separate banking regimes namely the onshore and offshore. Since then the legal framework has been modernized and the Banking Act was amended such that all banks are now governed by one single banking license. According to the Financial Sector Assessment Program, conducted by the World Bank and the IMF, Mauritius has a relatively large and well-developed domestic financial system and a growing offshore centre. 
Seetanah and Rojid (2006) found that $80 \%$ of the banks surveyed in Mauritius started some form of business process outsourcing in the early 1990's, and the remaining $20 \%$ started in the year 2000 . They argued that with respect to risk and portfolio management, almost the entire portfolio of banking products is accessible in digital form and many services are now available via the internet banking facilities. Furthermore, they pointed out that banks outsource four different categories of core banking activities namely, screening for loans, and recovery of debts, ATM management and credit bureau. Thus, for finance and accounting activities, transfer of technology risk appears to be the sole reason for outsourcing these activities.

Sharma (2009) explained that risk management has become more dynamic with derivatives and the introduction of Colonies Française d'Afrique and Mauritius Bankers Association will contribute a lot to the Mauritian economy. On the whole, index futures on the SEM-7 will allow for more price discovery to take place but investors will need to make sure that the fund house that manages their money has a sophisticated understanding of risk management.

Khadaroo (2008) argued that the resilience of the Mauritian banking sector to shocks has increased, in part due to diversification of the sources of bank's income. He explained that with a commodity exchange named Global Board of Trade (GBOT)Ltd in line with the Financial Technologies India(FTI) Ltd, launched in January 2009, intends to trade commodities and derivative products in metal ,oil and agriculture to boost up the Mauritian financial system a step further by enabling better enterprise risk management and financial planning.

\section{METHODOLOGY}

The methodology used for this study includes a survey questionnaire. The analysis of the questionnaires have been carried out using the Statistical Package for the Social Sciences (SPSS), which takes into account the possibility of dynamics feedbacks among the variable in the model. The questionnaire adopted in this study consists of 40 questions distributed over twelve aspects of risk and portfolio. The questionnaire is divided into two parts. The first part covers the six aspects: understanding risk and risk management; risk identification; risk assessment and analysis; risk monitoring; risk management practices and credit risk analysis. Respondents were asked to indicate their degree of agreement on a five-point likert scale. The second part deal with portfolio diversification, portfolio risk, international portfolio diversification and various assets classes for a well-portfolio diversification and portfolio investment.

\section{Data collection}

We have obtained data from 20 commercial banks, where the majority are involved in cross border activities. The targeted population are those heavily involved in the risk management process and where in 2009, their total assets exceeds 850 billion rupees of which 236 billion rupees is tied up in terms of 'Currencies and Deposits', according to the Central bank report ${ }^{3}$. Regarding the data collection, we handed questionnaires to the bank's head offices and branch managers who were requested to kindly pass the questionnaires to the targeted officers. The questionnaires were distributed to those officers involved in risk management activities, namely branch managers, senior risk management officers and senior credit officers as well as portfolio managers.

The reliability of the measures has been assessed with the use of Cronbach's alpha. Cronbach's alpha allows us to measure the reliability of different variables. It consists of estimates of how much variation in scores of different variables is attributed to chance or random errors (Selltiz, Wrightman and Cook. 1976). As a general rule, a coefficient greater than or equal to 0.7 is considered acceptable and a good indication of construct reliability (Nunnally, 1978). The overall Cronbach's alpha for the six aspects is (0.144) and Cronbach's alpha based on standardized items equals to (0.757).

\footnotetext{
${ }^{3}$ Refer to http:// bom.intnet.mu, "Sectoral Balance Sheet of Banks as at end December 2009”
} 


\section{ANALYSIS AND DISCUSSION}

Referring to Table 1 below, out of 20 banks, 11 do have a minimum number of markets in order to achieve a minimal portfolio diversification as well as banking products and services.

Table 1: Do bank products and services contribute to a Portfolio Diversification? Cross tabulated with Minimum number of markets in order to achieve a minimal portfolio diversification effect?

\begin{tabular}{|l|c|c|c|c|}
\hline \multicolumn{2}{|c|}{} & \multicolumn{2}{|l}{$\begin{array}{l}\text { Minimum number of markets in order to achieve a } \\
\text { minimal portfolio diversification effect? }\end{array}$} & Total \\
\cline { 3 - 5 } & Yes & 7 & 18 \\
\hline $\begin{array}{l}\text { Do bank products and services } \\
\text { contribute to a Portfolio } \\
\text { Diversification? }\end{array}$ & Yes & 11 & 0 & 2 \\
\hline \multicolumn{2}{|l|}{ Total } & 2 & 7 & 20 \\
\hline
\end{tabular}

Table 2, shows the degree of risk awareness that Mauritian banks is being faced where 13 commercial banks do have a risk communication strategy but the majority is facing high level of risk, for instance, where Grade 1(High): Aggressive banks who typically accept higher levels of borrowers and type of lending risk and are prone to enter and grow riskier types of lending. They may also accept larger exposures to indicate individual borrowers. Growth and market share are the true priorities as evidenced by the incentives placed on loan production. Simultaneously, Grade 2(Moderate): points out: Prudent banks, who accept some exposure to riskier borrowers or types of lending, but ensure that such loans are well secured. They Monitors riskier exposure closely to ensure that risk levels are acceptable. Cautious but not conservative lenders whose objective is credit performance comparable to peers and profit growth meets or exceeds peers. Finally, where Grade 3(Low): Banks who follow a conservative lending philosophy which emphasizes borrower's selection and conservative collateralization. Trend to avoid or limit exposure to high risk borrowers and types of lending. They are willing to sacrifice some amount of profitability to ensure consistent and superior credit performance.

Table 2 Characterize your institution's tolerance for risk cross-tabulated with does your organization has a risk communication strategy

\begin{tabular}{|c|c|c|c|c|}
\hline & & $\begin{array}{l}\text { Does your ory } \\
\text { strategy }\end{array}$ & communication & \\
\hline & & Yes & No & Total \\
\hline \multirow{3}{*}{$\begin{array}{l}\text { Characterize your institution's } \\
\text { tolerance for risk }\end{array}$} & 1 & 7 & 2 & 9 \\
\hline & 2 & 4 & 2 & 6 \\
\hline & 3 & 2 & 3 & 5 \\
\hline \multicolumn{2}{|l|}{ Total } & 13 & 7 & 20 \\
\hline
\end{tabular}

The respondent's answers on these nine questions indicate that the Mauritian banks' staff understands risk and risk management, giving a positive answer on the first question. However, there is not a big difference between the highest and the lowest means of the nine questions. The highest mean (23.35) indicates respondents viewed managing risk as crucial to the performance as well in population size concerning loans and mortgages on investment; the lowest mean (1.10) concerning whether risk is being analyzed in terms of reputation impact which is a feature of good risk management.

Risk identification is a very important aspect in risk management. The study questionnaire includes three questions about risk identification. The average means (4.30) indicates that the Mauritian banks have clearly identified the potential risks relating to their declared aims and objectives. Mauritian banks carry out a comprehensive and systematic identification of their risks. However, the result shows that banks neglect the internal and external flow of information about risks and benefits to the stakeholders. The questionnaire includes two questions about risk assessment analysis. The mean of the sample responses on the two questions is 3.463, which proves that banks are committed to risk assessment and analysis. 
Risk monitoring can be used to make sure that risk management practices are in line with desired practices. Proper risk monitoring also helps bank management to discover mistake early. The mean of the sample's responses on the four questions is 2.850 , which means that the banks try to cope with the 'risk monitoring processes'. Risk management practices might be considered the most important aspect of risk management. The questionnaire consists of nine questions towards the related topic and hence the highest mean (27.40) about 'risk management plan', following (20.50) on 'the implementation of Basel 2 in Mauritius'. The answers show that banks must be more aware on the application of the Basel Accord which was introduced to improve the efficiency of bank's risk management.

Credit risk represents the most important type of risk. The mean response on the seven questions is 5.478, which provides evidence of the efficiency of credit risk management in the Mauritian banking sector. The most important answers were on questions about collateral capital and conditions, non-performing assets about loan outstanding, default risk and Basel implementation on credit ratings. As our study follows, it is useful to examine the Cronbach's alpha concerning the portfolio diversification component. Overall Cronbach's alpha based on standardized items is 0.758

Table 3 shows the overall Cronbach's alpha of (0.758) concerning Portfolio Diversification

\begin{tabular}{|c|c|c|}
\hline \multicolumn{2}{|c|}{ Reliability Statistics } \\
\hline Cronbach's Alpha & Cronbach's Alpha Based on Standardized Items & N of Items \\
\hline .462 & .758 & 77 \\
\hline
\end{tabular}

\section{The Econometric Models}

H1: tries to test whether Mauritian banks reduce risks when Diversification of Portfolio takes place.

In order to test for H1, the following regression model is used:

Portfolio Diversification $=f($ Market risk + Solvency risk + Operational risk + Credit risk $)$

Using more than one variable to examine the contribution of independent variables concerning the regression may suggest multicollinearity problem among these variables. A multicollinearity test was carried out to assess the degree of correlation among variables and finally Pearson ${ }^{4}$ 's correlation was used to analyze correlations ${ }^{5}$ among the independent variables, namely (MR), (SR), (OPR) and (CR). The "rule of thumb" suggested by Anderson, Sweeney and Williams (1990) states that any correlation coefficient more than (0.7) indicates a potential problem. However, both Gujrati and Judge (1988) consider (0.8) to be the critical threshold for serious problems of multicollinearity. Pair wise correlation between two variables in our sample varies from -0.057 to 0.793 . Multicollinearity is possible if the correlation between two variables is very high. High multicollinearity increases variances of OLS estimator and lowers the significant levels of estimates. In sum, the results of correlations presented in table 4 suggest that there is no problem of multicollinearity among the independent variables.

As acknowledge by Brooks (2002), R square is the "most common goodness of fit statistics". It measures how much of the variation in $Y$ is explained by $X$. The value of $R$ square should lie between 0 and 1 . If the value of $\mathrm{R}$ square is high, it means that the model fits the data well. On the other hand, a low R square would mean the reverse. It can be seen that the $\mathrm{R}$ square's for each independent variables is $0.033,0.048,0.062$ and 0.121 respectively. This indicates that the four independent variables explain $3.3 \%, 4.8 \%, 6.2 \%$ and $12.1 \%$ of the variations in portfolio diversification. It can also be seen that the Durbin Watson is 2.019.According to Gujarati (2003), the DW statistic ${ }^{6}$ is a test statistic used to detect the presence of autocorrelation in the residuals from a regression analysis. The estimated coefficients of the four independent variables were as expected positive and

\footnotetext{
${ }^{4}$ Pearson's Correlation Coefficient is being used to measure the strength of the linear relationship between two variables

${ }^{5} \mathrm{We}$ use a two-tailed test to see if the two means are different from each other (i.e. from different populations), or from the same population

${ }^{6}$ See Durbin, J. ,and Watson, G.S. (1951) “ Testing for Serial Correlation in Least Square Regression”
} 
statistically significant at $5 \%$ level. It can be concluded that $\mathrm{H} 1$ of our research hypotheses is confirmed. Furthermore, the results indicate that operational risk, solvency risk and market risk were the most influencing variables on whether risks are being reduced when diversification of portfolio takes place. Hence this means that the Mauritian banks need to stress more on these particular types of risks.

Table 4 reveals the Correlations coefficients between independent variables

\begin{tabular}{|c|c|c|c|c|c|}
\hline & & $\begin{array}{l}\text { What are the risks } \\
\text { involved when not } \\
\text { diversify the } \\
\text { Portfolio(Market } \\
\text { risk/(systemic risk) }\end{array}$ & $\begin{array}{l}\text { What are the risks } \\
\text { involved when not } \\
\text { diversify the } \\
\text { Portfolio(Solvency } \\
\text { risk/liquidity risk) }\end{array}$ & $\begin{array}{l}\text { What are the risks } \\
\text { involved when not } \\
\text { diversify the } \\
\text { Portfolio(Operational } \\
\text { risk) }\end{array}$ & $\begin{array}{l}\text { What are the risks } \\
\text { involved when not } \\
\text { diversify the } \\
\text { Portfolio(Credit } \\
\text { risk) }\end{array}$ \\
\hline \multirow{5}{*}{$\begin{array}{l}\text { What are the risks } \\
\text { involved when not } \\
\text { diversify the } \\
\text { Portfolio(Market } \\
\text { risk/(systemic risk) }\end{array}$} & Pearson Correlation & 1 & $.454^{*}$ & $.572^{* *}$ & -.385 \\
\hline & Sig. (2-tailed) & & .044 & .008 & .094 \\
\hline & \begin{tabular}{|l|} 
Sum of Squares and \\
Cross-products
\end{tabular} & 222.950 & 45.500 & 40.950 & -12.600 \\
\hline & Covariance & 11.734 & 2.395 & 2.155 & -.663 \\
\hline & $\mathrm{N}$ & 20 & 20 & 20 & 20 \\
\hline \multirow{5}{*}{$\begin{array}{l}\text { What are the risks } \\
\text { involved when not } \\
\text { diversify the } \\
\text { Portfolio(Solvency } \\
\text { risk/liquidity risk) }\end{array}$} & Pearson Correlation & $.454^{*}$ & 1 & $.793^{* * *}$ & -.272 \\
\hline & Sig. (2-tailed) & .044 & & .000 & .246 \\
\hline & \begin{tabular}{|l|} 
Sum of Squares and \\
Cross-products
\end{tabular} & 45.500 & 45.000 & 25.500 & -4.000 \\
\hline & \begin{tabular}{|l|l} 
Covariance \\
\end{tabular} & 2.395 & 2.368 & 1.342 & -.211 \\
\hline & $\mathrm{N}$ & 20 & 20 & 20 & 20 \\
\hline \multirow{5}{*}{$\begin{array}{l}\text { What are the risks } \\
\text { involved when not } \\
\text { diversify the } \\
\text { Portfolio(Operational } \\
\text { risk) }\end{array}$} & Pearson Correlation & $.572^{\text {*** }}$ & $.793^{* * *}$ & 1 & -.057 \\
\hline & Sig. (2-tailed) & .008 & .000 & & .811 \\
\hline & $\begin{array}{l}\text { Sum of Squares and } \\
\text { Cross-products }\end{array}$ & 40.950 & 25.500 & 22.950 & -.600 \\
\hline & Covariance & 2.155 & 1.342 & 1.208 & -.032 \\
\hline & $\mathrm{N}$ & 20 & 20 & 20 & 20 \\
\hline \multirow{5}{*}{$\begin{array}{l}\text { What are the risks } \\
\text { involved when not } \\
\text { diversify the } \\
\text { Portfolio(Credit risk) }\end{array}$} & Pearson Correlation & -.385 & -.272 & -.057 & 1 \\
\hline & Sig. (2-tailed) & .094 & .246 & .811 & \\
\hline & $\begin{array}{l}\text { Sum of Squares and } \\
\text { Cross-products }\end{array}$ & -12.600 & -4.000 & -.600 & 4.800 \\
\hline & Covariance & -.663 & -.211 & -.032 & .253 \\
\hline & $\mathrm{N}$ & 20 & 20 & 20 & 20 \\
\hline
\end{tabular}

Table 5 shows a summary model of the regression results

\begin{tabular}{|c|c|c|c|c|c|}
\hline & \multicolumn{4}{|c|}{ Model } \\
\hline & & 1 & 2 & 3 & 4 \\
\hline \multicolumn{2}{|l|}{$\mathrm{R}$} & $.182^{\mathrm{a}}$ & $.220^{\mathrm{b}}$ & $.248^{\mathrm{c}}$ & $.347^{\mathrm{d}}$ \\
\hline \multicolumn{2}{|l|}{ R Square } & .033 & .048 & .062 & .121 \\
\hline \multicolumn{2}{|c|}{ Adjusted R Square } & -.021 & -.064 & -.114 & -.114 \\
\hline \multicolumn{2}{|c|}{ Std. Error of the Estimate } & .449 & .458 & .469 & .469 \\
\hline \multirow[t]{5}{*}{ Change Statistics } & R Square Change & .033 & .015 & .013 & .059 \\
\hline & F Change & .614 & .272 & .227 & 1.008 \\
\hline & df1 & 1 & 1 & 1 & 1 \\
\hline & df2 & 18 & 17 & 16 & 15 \\
\hline & Sig. F Change & .444 & .609 & .640 & .331 \\
\hline Durbin-Watson & & & & & 2.019 \\
\hline
\end{tabular}


In order to test the remaining two hypotheses, a one-way $\mathrm{ANOVA}^{7}$ was run.

H2: Is it good to diversify the portfolio locally?

In order to test for $\mathrm{H} 2$, the following regression model is used:

Portfolio Diversification $=f$ (Treasury Bills and other Government Securities + Property-Residential + PropertyCommercial+Equities+Claims on Private Sector+Cash in hand and Balances with Bank of Mauritius)

Table 6 shows the results for ANOVA analysis designed for Hypothesis 2

ANOVA

\begin{tabular}{|c|c|c|c|c|c|c|}
\hline & & Sum of Squares & df & Mean Square & $\mathbf{F}$ & Sig. \\
\hline \multirow{3}{*}{$\begin{array}{l}\text { What are the Asset Classes } \\
\text { that should be taken into } \\
\text { account for a well-Portfolio } \\
\text { Diversification(Cash in hand } \\
\text { and Balances with Bank of } \\
\text { Mauritius) }\end{array}$} & Between Groups & 80.000 & 2 & 40.000 & 4.250 & .032 \\
\hline & Within Groups & 160.000 & 17 & 9.412 & & \\
\hline & Total & 240.000 & 19 & & & \\
\hline \multirow{3}{*}{$\begin{array}{l}\text { What are the Asset Classes } \\
\text { that should be taken into } \\
\text { account for a well-Portfolio } \\
\text { Diversification(Property- } \\
\text { Residential) }\end{array}$} & Between Groups & 5.000 & 2 & 2.500 & .567 & .578 \\
\hline & Within Groups & 75.000 & 17 & 4.412 & & \\
\hline & Total & 80.000 & 19 & & & \\
\hline \multirow{3}{*}{$\begin{array}{l}\text { What are the Asset Classes } \\
\text { that should be taken into } \\
\text { account for a well-Portfolio } \\
\text { Diversification(Claims on } \\
\text { Private Sector) }\end{array}$} & Between Groups & 1656.200 & 2 & 828.100 & .567 & .578 \\
\hline & Within Groups & 24843.000 & 17 & 1461.353 & & \\
\hline & Total & 26499.200 & 19 & & & \\
\hline \multirow{3}{*}{$\begin{array}{l}\text { What are the Asset Classes } \\
\text { that should be taken into } \\
\text { account for a well-Portfolio } \\
\text { Diversification(Equities) }\end{array}$} & Between Groups & .300 & 2 & .150 & .309 & .738 \\
\hline & Within Groups & 8.250 & 17 & .485 & & \\
\hline & Total & 8.550 & 19 & & & \\
\hline \multirow{3}{*}{$\begin{array}{l}\text { What are the Asset Classes } \\
\text { that should be taken into } \\
\text { account for a well-Portfolio } \\
\text { Diversification(Investments in } \\
\text { Treasury Bills and other } \\
\text { Government securities) }\end{array}$} & Between Groups & 1.633 & 2 & .817 & .309 & .738 \\
\hline & Within Groups & 44.917 & 17 & 2.642 & & \\
\hline & Total & 46.550 & 19 & & & \\
\hline \multirow{3}{*}{$\begin{array}{l}\text { What are the Asset Classes } \\
\text { that should be taken into } \\
\text { account for a well-Portfolio } \\
\text { Diversification(Property- } \\
\text { Commercial -Real Estate) }\end{array}$} & Between Groups & .533 & 2 & .267 & .309 & .738 \\
\hline & Within Groups & 14.667 & 17 & .863 & & \\
\hline & Total & 15.200 & 19 & & & \\
\hline
\end{tabular}

Based on these findings, the banks can diversify their portfolio locally as there is a significance difference between Cash in hand and Balances with the Bank of Mauritius, Equities and Claims on Private Sector, according to ANOVA table and it can be said that $\mathrm{H} 2$ is confirmed. Relating to $\mathrm{H} 2$, it is wise to test whether it is better to diversify internationally.

H3: Is it better to diversify the portfolio internationally?

Portfolio Diversification $=f($ Off-balance sheet activities + Foreign Assets + Equities + Eurocurrency Markets $)$.

${ }^{7}$ One-way ANOVA is being used in order to test the equality of three or more means at one time by using variances 
Table 7 shows the results for ANOVA analysis designed for Hypothesis 3

\begin{tabular}{|c|c|c|c|c|c|c|}
\hline \multicolumn{7}{|c|}{ ANOVA } \\
\hline & & Sum of Squares & Df & Mean Square & $\mathbf{F}$ & Sig. \\
\hline \multirow{3}{*}{$\begin{array}{l}\text { What are the Asset Classes } \\
\text { that should be taken into } \\
\text { account for a well-Portfolio } \\
\text { Diversification(OBS - off- } \\
\text { balance sheet activities) }\end{array}$} & Between Groups & 2.067 & 2 & 1.033 & 2.160 & .146 \\
\hline & Within Groups & 8.133 & 17 & .478 & & \\
\hline & Total & 10.200 & 19 & & & \\
\hline \multirow{3}{*}{$\begin{array}{l}\text { What are the Asset Classes } \\
\text { that should be taken into } \\
\text { account for a well-Portfolio } \\
\text { Diversification(Foreign } \\
\text { Assets) }\end{array}$} & Between Groups & 37.800 & 2 & 18.900 & 5.950 & .011 \\
\hline & Within Groups & 54.000 & 17 & 3.176 & & \\
\hline & Total & 91.800 & 19 & & & \\
\hline \multirow{3}{*}{$\begin{array}{l}\text { What are the Asset Classes } \\
\text { that should be taken into } \\
\text { account for a well-Portfolio } \\
\text { Diversification(Equities) }\end{array}$} & Between Groups & 1.050 & 2 & .525 & 1.190 & .328 \\
\hline & Within Groups & 7.500 & 17 & .441 & & \\
\hline & Total & 8.550 & 19 & & & \\
\hline \multirow{3}{*}{$\begin{array}{l}\text { What are the Asset Classes } \\
\text { that should be taken into } \\
\text { account for a well-Portfolio } \\
\text { Diversification(Property- } \\
\text { Commercial -Real Estate) }\end{array}$} & Between Groups & 1.867 & 2 & .933 & 1.190 & .328 \\
\hline & Within Groups & 13.333 & 17 & .784 & & \\
\hline & Total & 15.200 & 19 & & & \\
\hline \multirow{3}{*}{$\begin{array}{l}\text { According to you, do Cross- } \\
\text { border Activities contribute for } \\
\text { International Portfolio } \\
\text { Investment? }\end{array}$} & Between Groups & .000 & 2 & .000 & . & . \\
\hline & Within Groups & .000 & 17 & .000 & & \\
\hline & Total & .000 & 19 & & & \\
\hline
\end{tabular}

It can be argued referring to Hypothesis 3 that there is a difference between the different assets classes with regards to international portfolio diversification. Hence as per table 7, where it can be concluded that there is a significant difference between OBS activities, FA and EQ $(0.146,0.011$ and 0.328$)$ respectively. These results were expected because it is assumed that international portfolio diversification reduces banking risks but at least the Mauritian banks should lay emphasis on their foreign assets and off- balance sheet activities. However, H3 is confirmed.

But in order to move ahead, Mauritius needs however to further diversify its financial sector as in overall the financial sector is in good health and the short term stability risks are modest. In terms of managing risks, facing in the banking system, there is a need to encourage banks to enforce their internal control, fostering the development of alternatives to bank lending to reduce portfolio concentrations and increase competition in such a way that encouraging sound international risk diversification and finally reducing the government's implicit contingent liability in the banking system. Opportunities for portfolio diversification are constrained by the structure of the small island economy. While portfolio concentrations are to some degree unavoidable, the recent tightening of Bank of Mauritius guidelines on large exposures and related-party lending represents a positive development. To guard against deterioration in the value of their portfolios, banks have been minimizing their exposures to sectors where the risk is considered highest.

\section{CONCLUSION AND RECOMMENDATION}

The importance of risk management and portfolio diversification in the banking sector has received much consideration in the recent literature. A strong attention is being put forward concerning the impact of risks in financial intermediaries and thus it is better to diversify the risks with a well-diversified portfolio, according to the recent financial crisis which had laid banks to react promptly to several changes in the financial system as a whole. The Basel 2 regulation is likely to add fuel in this regards because new rules on how much capital banks must hold, will make a few lending decisions even more profitable. Carey (2001) indicates that risk management is more important in the financial sector than in other parts of the economy. The purpose of financial institutions is to maximize revenues and present the most value to shareholders by offering a variety of financial services which definitely will contribute for a well-diversification of banking portfolios and especially by administering risks. 
Recently, many commercial banks have appointed senior managers to oversee a formal risk management function. Thus, financial intermediaries may avoid specific risks by simplifying business practices and minimizing activities that inflict risk. Activities with which the financial institution is committed to proceed can be adeptly managed or transferred in such a way to minimize portfolio risk according to Markowitz (1959). Certain risks which are inevitable or transferred must be engulfed by the bank. The concept of portfolio diversification tends to become more and more applicable towards the banking sector of Mauritius and for instance referring to our methodology, portfolio diversification helps banks to reduce their risks in such a way that credit risk is being managed on a continuous basis supported with Basel 2 implication on credit risk weightage. One of our findings suggested that there is a positive relationship between risk management practices, understanding risk, risk management, risk identification, risk assessment and analysis, risk monitoring and finally credit risk analysis.

Based on our findings, it can be deducted that Mauritian banks are able to handle positively the risk management processes but should lay more emphasis on certain types of risk prior to risk management practices especially market risk, operational risk and precisely credit risk unless in our data analysis it was found that there is a significant difference between credit risk when diversification of portfolio's take place. Banks should concentrate more on these types of risks not only to reduce probability of default but additionally to support the economy as a whole in case of a financial distress.

Basically, it is found through a test of reliability of measures namely the Cronbach's alpha that on overall aspects, risk management and portfolio diversification variables have a positive impact on our field of study, for instance a coefficient greater than or equals to 0.7 is considered acceptable and a good indication of construct reliability according to Nunnally (1978). However, the banks should be cautious on the fact that understanding risk management, risk management processes, risk assessment and analysis are the main variables that affect both risk management practices as well as portfolio diversification.

Following our analysis, it is being observed that risks are being reduced when diversification of portfolio takes place and as such based on some statistical and econometrics models, it is confirmed that risks are being managed whether diversifying the portfolio locally or internationally. Nevertheless, according to fresh data being collected, it is found that most of our respondents prefer to diversify their portfolios both locally and internationally with the sole aim to minimize the probability of default and to minimize foreign exchange exposure related to crossborder activities.

\section{AUTHOR INFORMATION}

M.P Odit is a full-time lecturer at the University of Technology, Mauritius (UTM). He received his MPhil degree from UTM. He holds the degrees of MBA and BCom from Pune University, India. He is Officer in Charge of the Dept of Public Policy and Management, School of Business Management and Finance, UTM. He has authored/Coauthored in several journals and his area of research includes corporate investment, financial leverage, risk management economic growth, reform in taxation and education.

Mrs. K. Dookhan is a full-time lecturer at the University of Technology, Mauritius. She holds a Bachelor of Commerce specializing in Banking and Finance and Cost and Works Accounting from the University of Pune, India, a Master in Business Administration (with First Class) in Finance from the University of Pune, India.

Mr. J.C Marylin works as research assistant under the guidance of Mr. Odit M.P. He holds a Bachelor's Degree in Banking and International Finance from University of Technology, Mauritius.

\section{REFERENCES}

1. Ali-Yrkko, J., (2002) 'Mergers and Acquisitions: Reasons and Results', The Research Institute of the Finnish Economy, Finland, Helsinki.

2. Allen, F.and Santomero, M., (1998) 'The Theory of Financial Intermediation', Journal of Banking and Finance, Vol.21, pp.1461-1485. 
3. Arouri, M., (2004) 'The Impact of Increasing Stock Market Integration on Expected Gains from International Portfolio Diversification: Evidence from a Multivariate Approach with Time Varying Risk', Economics Bulletin, Vol.6 No.3, pp.1-13.

4. Basel Committee on Banking Supervision (1999), 'Principles for the management of credit risk', consultative paper issued by the Basel Committee on Banking Supervision, issued for comment by 30 November, p.3

5. Bearle, L.De Jonghe, O.and Vennet, R., (2006) 'Does the Stock Market Value Bank Diversification?' August, 2006, available at SSRN:http://ssrn.com/abstract:883593.

6. Brooks, C., (2002) 'Introductory Econometrics for Finance', Cambridge University Press, pp.701, ISBN: 052179367-X (paperback), 0521790182 (hardback).

7. Buffet, W., (2007) 'How to make money, The Buffett Way: Money and Business', US. News: $\underline{\text { u.snews.com }}$ by Alex Markels.

8. Butler, K.and Joaquin, C., (2001) 'Are the Gains from International Portfolio Diversification Exaggerated?' December 2001, Journal of Inter Money and Finance, Vol.21, issue 7, pp.981-1011.

9. Carey, A., (2001) 'Effective risk management in financial institutions: The Turnball Approach', Balance Sheet, Vol. 9 No.3, pp.24-7.

10. Cerpedes, G.Herrero, J. Kreinin, A and Rosen, D., (2006) 'A Simple Multi-Factor: Factor Adjustments for The Treatment of Credit Capital Diversification', Journal of Credit Risk, Forthcoming.

11. Dembo, R., (2006) 'Upside, Downside: Simple Rules of Risk Management for the Smart Investor', Mifflin, 2006.

12. Ellis,k.,(2008) 'Investment Performance, Asset Allocation and Expenses of Large Superannuation Funds', Working Paper, APRA, October, 2008,pp.9-12, katrina.ellis@apra.gov.au

13. Gerard, J., (2009) 'Opportunities for Risk Management', Business Week, August 21, 2009.

14. Gujarati, D.N., (2003) 'Basic Econometrics', $4^{\text {th }}$ edition, Boston, McGraw-Hill.

15. Hahm, J.H., (2004) 'Interest rate and exchange rate exposures of banking institutions in pre-crisis Korea', Applied Economics, Vol. 36 No.13, pp.1409-19.

16. Hanson, G.Persaran, H.and Schuermann, T., (2005) 'Firm Heterogeneity and Credit Risk Diversification', CES ifo Working Paper series No.1531.

17. Hellwig, M., (1998) 'Banks, Market and the allocation of Risk', Journal of Institutional and Theoretical Economics, No.154, pp.328-351.

18. Khadaroo, J., (2008) 'Futures Developments in the Banking and Financial Sector in Mauritius', August 25, 2008, pp.1-3, University of Technology, Mauritius.

19. Linbo Fan, L., (2004) 'Efficiency versus risk in large domestic US', Managerial Finance, Vol. 30 No.9, pp.1-19.

20. Litan, R., (1985) 'Evaluating and Controlling the risks of Financial Product Deregulation', Yale Journal on Regulation, pp.1-52.

21. Miller, M., (1972) and Modigliani, F., (1980) 'Corporate Risk Management and Optimal Hedging', The Collected Papers of Franco Modigliani, Vol.3, pp.6-14, Cambridge, Massachusetts: MIT Press.

22. Markowitz, H., (1952) 'Portfolio Selection', Journal of Finance, John Wiley, New York, pp.77-91.

23. Markowitz, H., (1959) 'Portfolio Selection: Efficient Diversification of Investment', Journal of Finance, John Wiley, New York

24. Niinimaki, J.P., (2004) 'The effects of competition on bank's risk taking', Journal of Economics, Vol.81 No.3.pp.199-222.

25. Nunnally, CJ., (1978) 'Psychometric Theory', McGraw-Hill, New-York, NY.

26. Nusbaum, R., (2008) 'A Diversified Portfolio should take Risks, but Not a lot', March 23, 2008.

27. Pytkin, M., (2004) 'Multi-factor adjustment', Risk, Vol.17.pp.85-90.

28. Rarimohan,R .,(2001) 'Risk Management in Commercial Banks', Indian Institute of Capital Markets, $9^{\text {th }}$ Capital Market Conference Paper, Bapuji Institute of Engineering and Technology, University of Mysore.

29. Reeves, C., (2005) 'Risk Management and the Magic of Diversification', Newspapers, Hedgeweek, pp.1345.

30. Reisen, H., (2000) 'Pensions, Savings and Capital Flows from Ageing to Emerging Markets', Department Centre Studies, OECD, Paris. 
31. Seetanah,B.andRojid,S.,(2006) 'Outsourcing In The Mauritian Banking Sector', Conjoncture,published by PluriConseil Ltd,pp.1-2,Dr. Seetanah, Senior Lecturer at The University of Mauritius and Mr.Rojid,Consultant, Economist for The World Bank.

32. Selltiz, C., Wrightsman, L.S. and Cook, W., (1976) 'Research Methods in Social Relations', Holt, Rinehart and Winston, New York, NY.

33. Sercu, P., (1980) 'A Generalization of the International Asset Pricing Model', Association Française de Finance, No.1, pp.91-135.

34. Sharma, S., (2009) 'Managing Portfolios and Central Bank Independence', Conjoncture, published by PluriConseil Ltd, pp.3-5, www.pluriconseil.com

35. Sinkey Jr, J., (1984) 'Commercial Bank Financial Management', Macmillan, New York and Collier Macmillan, London 1983.

36. Solnik, B., (1973) 'European Capital Markets', Lexington Books, Lexington Mass.

37. Stiroh,J.,(2006) 'A Portfolio View of Banking with Interest and Non-Interest Activities', Journal of Money Credit and Banking,Vol.38(5),pp.1351-1361.

38. Thompson, C., (2008) 'Three opportunities for Risk Management', Willis UK and Ireland, May 15, 2008.

39. Wetmore, J.L.,(2004) 'Panel data, liquidity risk and increasing loans-to-core deposits ratio of large commercial bank holding companies', American Business Review, Vol. 22 No.2,pp.99-107.

40. Wright, R and Buffet, W., (2006) 'Does it pay to be the next Buffett', Davis Advisors, New York, May 6, 2006, dahhuilaudavid.blogspot.com/2006/

41. Wright, T., (2008) 'Understanding Risks', National Bank Financial, Terry Wright, CIM, Investment Advisor, terry.wright@nbf.ca 